\title{
Spatial and temporal patterns in barnacle settle- ment rate along a southern California rocky shore
}

\author{
Jesús Pineda* \\ Scripps Institution of Oceanography, University of California, San Diego, La Jolla, California 92093-0208, USA
}

\begin{abstract}
Barnacle settlement was monitored at 5 sites separated by 50 to $250 \mathrm{~m}$ at Dike Rock, La Jolla, California, USA. Chthamalus spp. and Pollicipes polymerus settlement were spatially correlated at those sites. Within sites, settlement of the 2 species were correlated These results support the hypothesis of common onshore larval transport events for all sites and both species. Other spatiotemporal patterns were contrasting: 1 peak accounted for most of $P$. polymerus settlement, while there were 5 peaks of similar magnitude for Chthamalus spp. At 2 sites, settlement plates were installed at 2 heights in the intertidal; Chthamalus spp. settlement was similar at the 2 heights, while P. polymerus settlement was relatively different at the sites. Such spatial patterns may have resulted from a stronger behavioral component affecting settlement in $P$. polymerus. These results suggest that, at scales of $100 \mathrm{~m}$, temporal variability in settlement rate may be related to larval pool and physical transport processes, while spatial variability may be associated with behavioral response and substrate availability. Chthamalus spp. settlement was higher at sites where rocks were surrounded by unsuitable sandy substrate, possibly because settlement on available substrate is intensified where total suitable settlement area is relatively scarce. To test this, plates were installed at another site where suitable substrate was also scarce; as predicted, settlement was higher at both sites. At another study site in Medio Camino, Mexico, settlement became more predictable among sites along the rocky shore after the shoreline had been partially inundated by sand, further supporting this hypothesis. The proportion of unmetamorphosed settlers of Chthamalus spp., relative to total settlement, appeared to peak on particular days of the lunar cycle and was spatially correlated at the 5 sites. The periodicity of the peaks was close to the $14.75 \mathrm{~d}$ spring-to-neap cycle, suggesting that these peaks may be related to periodic shortimmersion times that did not allow the attached cyprids to metamorphose. Mortality of recently metamorphosed $(\leq 1$ d) Chthamalus spp. spat by physical damage was spatially variable.
\end{abstract}

KEY WORDS: Settlement · Chthamalus spp. Pollicipes polymerus · Spatial and temporal variability

\section{INTRODUCTION}

Recent interest in the ecology of larval settlement in the intertidal zone (e.g. Young 1990) has focused on distinguishing how settlement vs post-settlement processes influence population abundance (Connell 1985). Distribution and abundance of many intertidal marine benthic populations are influenced by disturbance and biotic interactions among established adults (Hatton 1938, Connell 1961, Paine 1966, Dayton 1971. Taylor \& Littler 1982) whose initial numbers depend on processes influencing settling larvae: micro-

\footnotetext{
- Present address: Biology Department, Woods Hole Oceanographic Institution, Woods Hole, Massachusetts 02543, USA
}

hydrodynamic events, behavior, substrate availability, and predation within and among settlement sites (Denley \& Underwood 1979, Keough \& Downes 1982, Grosberg 1982, Eckman 1983, Gaines et al. 1985, Butman 1987, Bushek 1988, Young 1988, Raimondi \& Keough 1990, Minchinton \& Scheibling 1991, Raimondi 1991, Bertness et al. 1992). The number of larvae available to these processes is, in turn, determined by the rate of arrival of larvae on the shore, which depends on physical transport processes (Hatton 1938, Bousfield 1955, Hawkins \& Hartnoll 1982, Kendall et al. 1985, Shanks 1983, 1986, Gaines \& Roughgarden 1985, Gaines et al. 1985, Scheltema 1986, Roughgarden et al. 1988, Farrell et al. 1991, Pineda 1991, Gaines \& Bertness 1992). Finally, the 
number of larvae avajlable to physical transport depends on phenomena which influence the larval pool (Johnson 1939, 1960, Korringa 1941, Thorson 1950).

Studies on the temporal and spatial scales of settlement have generally revealed great variability: among geographic locations (Bennell 1981, Hawkins \& Hartnoll 1982, Kendall et al. 1982, Caffey 1985, Wethey 1986, Dayton et al. 1989), among sites along a beach (Hatton 1938, Connell 1961, Denley \& Underwood 1979, Keough \& Downes 1982, Gaines et al. 1985, Caffey 1985, Bushek 1988, Raimondi 1991) and also within sites (De Wolf 1973, Hawkins \& Hartnoll 1982, Wethey 1984, Gaines \& Roughgarden 1985; see also Crisp 1976 for a review of smaller scales).

Settlement rate, the rate at which planktonic larvae establish permanent contact with the substrate (e.g. Connell 1985), depends on the rate of arrival of larvae on the shore (which depends on the larval pool and physical transport processes), on suitable settlement substrate, and on micro-hydrodynamic and behavioral processes (Fig. 1). Measurement of settlement rate can offer insights into these processes. Knowledge of settlement patterns along a shore could help explain issues related to onshore transport of larvae. Peaks in larval settlement correlated in space (along the shore) and in time (at the same site for 2 different species) would support an hypothesis of common events affecting onshore transport of larvae and might shed some light on the spatial scale of the transporting phenomenon. Shanks \& Wright (1987) counted attached cyprids and metamorphs on 2 dates separated by $\sim 25 \mathrm{~d}$ and found that settlement was higher in an area of 'higher return of surface drifters' (by 'internal wave slicks')

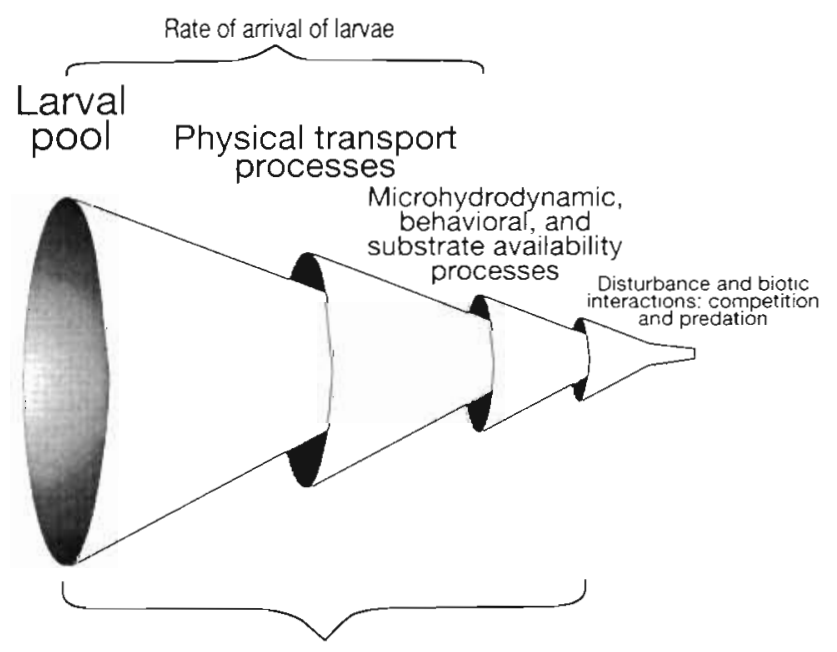

Processes influencing settlement rate

Fig. 1. Representation of the proximate processes that influence settlement rate and populations' abundance and distribution in benthic communities than in areas with low returns. In these experiments, 6 sites were arranged inside a small bay $(\sim 600 \mathrm{~m}$ entrance width). Farrell et al. (1991) studied onshore transport of larvae and barnacle settlement (measured every other day) at 6 sites separated by -2 to $20 \mathrm{~km}$ and reported detailed results from 2 sites where settlement rate appeared to be spatially correlated. No results were presented for the other sites. Caffey (1985) showed that peaks in abundance of barnacle settlers ( 0 to $30 \mathrm{~d}$ old) tended to correlate among 6 sites (20 to $50 \mathrm{~m}$ apart) within each of 3 shores studied. Wethey (1986) measured daily settlement at shores separated by 25 to $50 \mathrm{~km}$ and found some evidence of spatial correlation. Influence of available settlement substrate could also be studied by inspecting settlement rates within sites (Denley \& Underwood 1979, Gaines \& Roughgarden 1985, Minchinton \& Scheibling 1993) and among sites (Bertness et al. 1992). Effects of micro-hydrodynamics on settlement rates have been usually studied with models or laboratory flumes (Eckman 1983, Butman 1987), and effects of behavior have focused on distribution (Strathmann et al. 1981 . Keough \& Downes 1982, Wethey 1984, Raimondi 1991); effects of behavior on settlement rates could also be inferred by comparing species with different behavior at settlement (e.g. Knight-Jones 1953, Johnson \& Strathmann 1989)

In this paper, larval settlement was observed on rocky shores (scale of 100 s of meters) for 2 species of barnacles, Chthamalus spp. and Pollicipes polymerus, and patterns in the proportion of attached unmetamorphosed cyprids to total settlement and in spat mortality were documented. Questions addressed include the following: What are the spatial and temporal patterns of settlement variability within a particular intertidal area? Is settlement by Chthamalus spp. and P. polymerus spatially correlated at $100 \mathrm{~m}$ scales? Is settlement within sites temporally correlated for the 2 species? Is settlement predictably different in some parts of the shore? If so, what processes are responsible? What processes influence the variability in the proportion of unmetamorphosed settlers to total settlement? What are the spatial and temporal patterns of spat mortality on a beach? Is mortality spatially variable? Is mortality spatially correlated?

\section{METHODS}

Settlement plates were sampled at various frequencies (see below) for attached Pollicipes polymerus, and attached cyprids, metamorphosed spat, and 'dead metamorphosed spat' of Chthamalus spp. (In this paper, 'metamorphs' are Chthamalus spp. which have lost their cyprid shell, while 'unmetamorphs' refers to 
attached cyprids that have not lost their shell.) Mortality events were recognized by an obviously damaged individual Chthamalus spp. (cut in half, crushed, spat scar, etc.). The mortality estimate (number of dead spat/total settlement) was thus conservative because non-metamorphosed dead cyprids or consumed spat (see 'Discussion') were not quantified, and because dead but not obviously damaged spat would have been missed. Upon removal, settlement plates were replaced with fresh plates that had been thoroughly scrubbed in fresh water.

Settlement plates were made of white polyvinyl chloride pipes cut in half through their longitudinal axes. Three grooves were machined into the inner surface of each plate. The total length of the grooves was $58 \pm 0.4 \mathrm{~cm}$ (mean $\pm \mathrm{SD}, \mathrm{n}=10$ ). Settlement was only counted for barnacles within about $0.0165 \mathrm{~cm}$ of the groove axis, leading to an estimate of $1.9 \mathrm{~cm}^{2}$ of available substrate per plate. Sampled plates were inspected using a dissecting microscope. As in other barnacle species (Crisp \& Barnes 1954, Wethey 1984) settling Chthamalus spp. and Pollicipes polymerus larvae strongly prefer grooves. Most barnacles settling on the plates were found within the limits of the sampled groove area. Exceptions occurred on dates with very high settlement. Plates were perforated in the middle (hole diameter was $\sim 1.2 \mathrm{~cm}$ ) so that they could be mounted on the substrate with plastic screws. These screws were cemented to rock holes with epoxy resin. Substrate around installed plates contained Chthamalus spp. but plates were at least $50 \mathrm{~cm}$ from $P$. polymerus aggregations.

Sampling was performed at 2 locations. Plates were sampled daily at Dike Rock, La Jolla, California $(\sim 500 \mathrm{~m}$ north of the pier at Scripps Institution of Oceanography) in 1989. Five sites (O, A, B, C and D) were occupied at different times for identifying specific patterns or for testing specific hypotheses (see below). Sites were arranged along shore, separated by

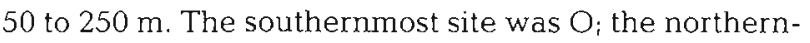
most site was $D$. Sites $O \& D$ were at the periphery of the rocky shore, where the sandy and rocky habitats overlap. Each site had at least 3 plates (separated 0.5 to $2 \mathrm{~m}$ per site), 1 or 2 horizontally oriented and 1 or 2 vertically oriented.

The second location, Medio Camino, northern Baja California, Mexico, is about $100 \mathrm{~km}$ south of Dike Rock. Five sites ( 1 to 5), separated by about 10 to $60 \mathrm{~m}$, were sampled every other day in April-May and on $4 \mathrm{~d}$ intervals in August-September 1991. (In one instance in the April-May experiment, plates were sampled at a $4 \mathrm{~d}$ interval.) The southernmost site was 1 . One plate was installed per site, orientated horizontally.

Plates at both locations were about 0.75 to $1.50 \mathrm{~m}$ above mean lower low water (MLLW) level, except for a second set of plates installed at Dike Rock, Sites A $\& \mathrm{~B}$, at about 0.2 to $0.5 \mathrm{~m}$ above MLLW (referred to Sites A-low and B-low.)

All statistical tests were performed on the average of data from 2 to 3 plates per site at Dike Rock, and the data from 1 plate at Medio Camino. Non-significance (ns) was set at $\alpha>0.05$. A periodogram analysis (Schuster 1898, explained in Enright 1965) was performed by plotting amplitude, $A_{p}$ vs period, $p$, from data on the proportion of unmetamorphosed settlers. Root mean square $A_{p}$ was obtained as in Enright (1965):

$$
A_{p}=\sqrt{\frac{1}{P} \sum_{h=1}^{P}\left(Y_{p, h}-\overline{Y_{p}}\right)^{2}} \text { where } \overline{Y_{p}}=\frac{1}{P} \sum_{h=1}^{P} Y_{p, h}
$$

Enright defined $p$ as 'the period for which form is to be estimated (need not be an integer)', $P$ as the 'largest integer $\leq p$ ', $h$ as the day for which the average is to be computed 'an integer $(0<h \leq P)^{\prime}$, and $Y_{p, h}$ as the mean daily value for the $h$ th day value 'of the form estimate for assumed period, $p$ '. For obtaining fractional periods from a series sampled at 1 whole unit intervals (or in general higher intervals than the resolution of period desired) there are several interpolation techniques. The one used here was explained by Enright (1965) and is based on advancing through the time series at the average rate of the fractional period desired.

In this paper, spatial correlation is used for correlation over some time of the individual species among sites (irrespective of the other species), while temporal correlation is the correlation between Chthamalus spp. and Pollicipes polymerus within one site independent of other sites.

\section{RESULTS AND HYPOTHESES}

\section{Settlement patterns at Dike Rock}

There were several peaks in settlement for Chthamalus spp. and Pollicipes polymerus from April through July (Figs. $2 \& 3$ ). Increases and decreases in settlement for both species were often abrupt (e.g. for Chthamalus spp., June 14, 15 and 16 for Sites A, B \& O, and June 21 and 22 at Sites A \& O, Fig. 2; for P. polymerus, June 14,15 and 16 for Site $B$, and June 10, 11 and 12 for Sites O \& C, Fig. 3). Chthamalus spp. and $P$. polymerus settlements were temporally correlated with each other within Sites A \& B (the sites with the longest series; Spearman $r_{5}=0.589$, $\mathrm{n}=93$ for Site A and $r_{\mathrm{s}}=0.715, \mathrm{n}=95$ for Site $\mathrm{B}_{\text {; }}$ in both cases $\mathrm{p}<0.05$ ).

While peaks in settlement appear to coincide, other settlement patterns for Chthamalus spp. and Pollicipes 
polymerus are contrasting. Chthamalus spp. settlement peaks were of similar order of magnitude throughout the sampling period. P. polymerus had a relatively low settlement rate until an exceptionally high settlement occurred in late July to early August. Chthamalus spp. settlement intensities per site appear similar in magnitude within the 5 sites, but for P. polymerus, Site B appears to have higher settlement intensities than the other sites. A Wilcoxon signed-rank test comparing settlement between Sites A \& B (the longest series) showed no consistent difference in Chthamalus spp. $(z=0.41, n=102, n s)$ but $P$. polymerus showed evidence of statistical differences at those sites $(z=4.99$, $\mathrm{n}=92, \mathrm{p}<0.05$ ).

\section{Vertical differences in settlement at Dike Rock}

For the lower intertidal plates, there was no evidence of consistent differences in settlement between Sites A-low and B-low for Chthamalus spp. (Wilcoxon signed-rank test $z=-1.245, \mathrm{n}=35, \mathrm{~ns})$ nor for Pollicipes polymerus $(z=-1.412, \mathrm{n}=32$, ns). There was no evidence of consistent differences in Chthamalus spp. settlement between Sites A and A-low ( $z=1.796$, $\mathrm{n}=33, \mathrm{~ns})$ nor evidence of differences between Sites $\mathrm{B}$ and B-low $(z=-1.188, \mathrm{n}=35$, ns). For $P$. polymerus, there was evidence of statistical differences between Sites A and A-low $(z=3.200, \mathrm{n}=27$, $p<0.05$, with Site A-low having more settlement than Site A) as well as between Sites B and B-low $(z=-2.416, \mathrm{n}=29, \mathrm{p}<0.05$, with Site B-low having less settlement than Site B).

\section{Settlement variability along the shore at Dike Rock}

A peak in settlement occurring synchronously at several sites along a rocky shore could be evidence that larvae were transported onshore by the same physical event; spatial correlation of settlement within the shore supports the event idea in cases where the spatial scale of physical transport phenomena is larger than the extent of the rocky shore. (Other alternatives are evaluated in the 'Discussion'.) The hypothesis that settlement was coherent at several sites along Dike Rock was tested by considering the temporal patterns in daily Chthamalus spp. and Pollicipes polymerus settlement at Sites $O$ to $C$. Fig. 2 shows that Chthamalus spp. daily settlement variability at Sites $O$ to $C$ and Site $D$ appears to be correlated at the 5 sites. Spearman $r_{s}$ correlation coefficients among stations were all significant $(p<0.05$; Table 1$)$. Site $O$ typically had higher settlement than the other sites. Fig. 3 shows settlement variability for $P$. polymerus. Spatial variability in $P$. polymerus appeared to be less correlated across sites than in Chthamalus spp.; Spearman $r_{s}$ correlation coefficicnts (Table 2) were all significant, but their magnitude was smaller than those for Chthamalus spp. in every case.

\section{Decreased-substrate settlement-intensification hypothesis}

Potential settlement $(S)$ can be defined as $S=N / A$, where $N$ is number of potential settlers over a site; and $A$ is suitable settlement area. Variability in potential

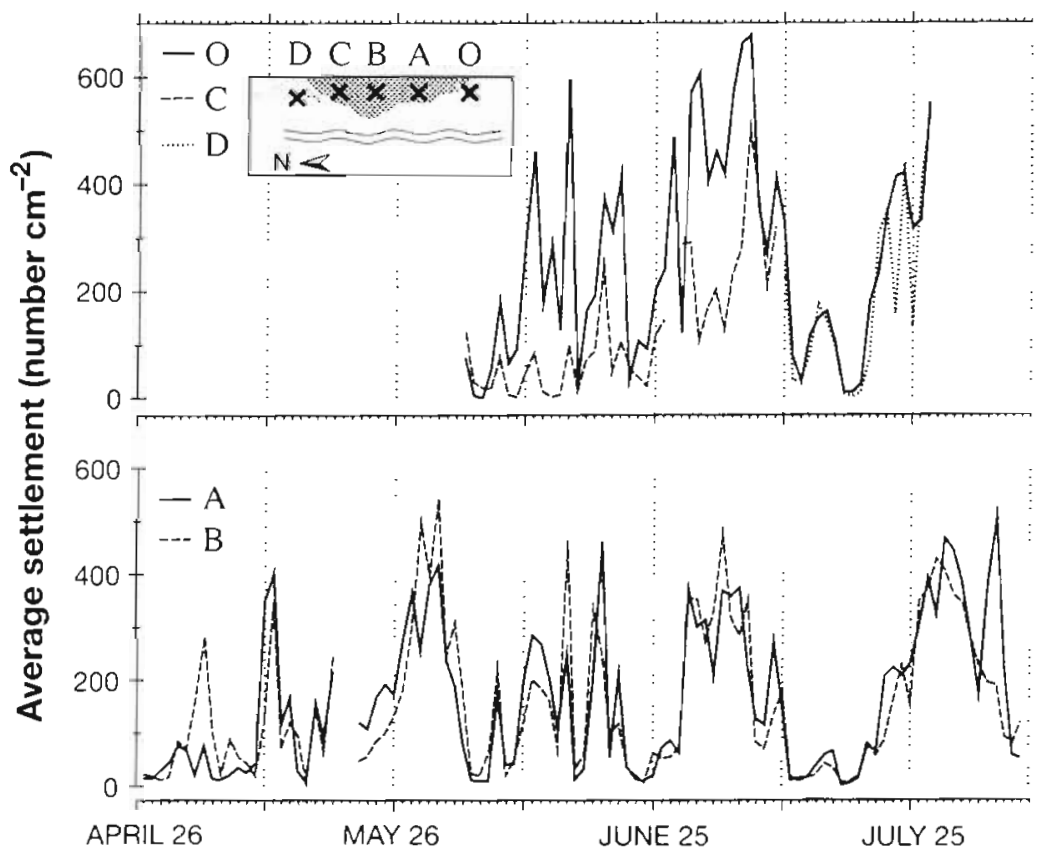

Fig. 2. Chthamalus spp. Daily settlement rate of metamorphosed spat plus attached cyprids at Dike Rock. Sites were arbitrarily segregated between upper and lower panels to clarify graphs. Breaks in lines represent missing data. Insert shows arrangement of sites, where the dark shading represents the rocky area and the light shading represents the sandy shore 


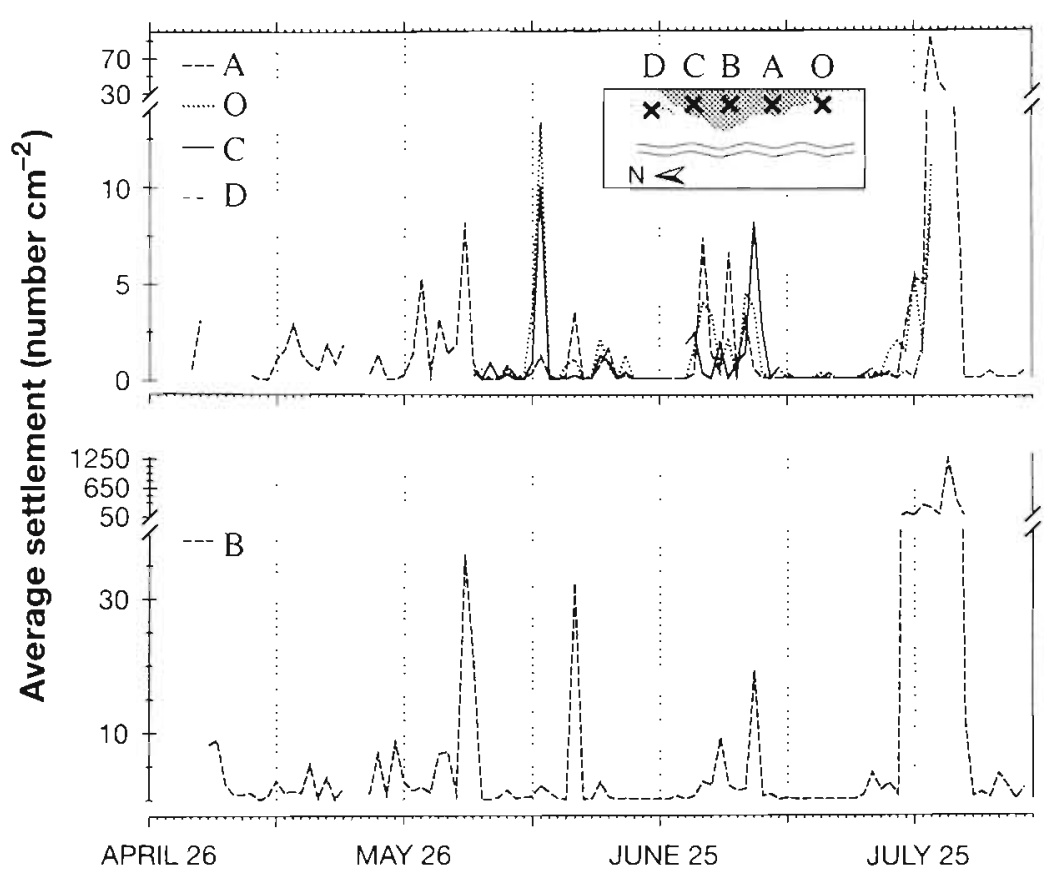

Fig. 3. Pollicipes polymerus. Daily settlement rate of attached barnacles. Details as in Fig. 2

settlement rate may be related to changes in either $N$ or $A$. Consider the case of a decrease in $A$ (corresponding to an example discussed below). A decrease in suitable substrate would produce an increase in $S$ at constant $N$. The decreased-substrate settlementintensification hypothesis proposes that settlement intensification results from a decrease in suitable substrate $A$. In this study, increased Chthamalus spp. settlement occurred at the extremes of rocky-shore habitat, where suitable substrate is scarce. This hypothesis also explains settlement intensification in rocky shores undergoing seasonal or non-seasonal sand inundation (see 'Discussion'); inundation by sand would cause a net decrease in settlement substrate available

Table 1. Chthamalus spp. Spearman $I_{s}$ correlation coefficients among sites for settlement. $p \leq 0.05$

\begin{tabular}{|c|c|c|c|c|c|}
\hline & 0 & A & B & $\mathrm{C}$ & D \\
\hline $\mathrm{O}$ & - & $\begin{array}{l}0.871^{\circ} \\
\mathrm{n}=55\end{array}$ & $\begin{array}{l}0.827^{\circ} \\
n=55\end{array}$ & $\begin{array}{l}0.662^{\circ} \\
\mathrm{n}=36\end{array}$ & $\begin{array}{l}0.911^{\circ} \\
\mathrm{n}=18\end{array}$ \\
\hline A & & $\begin{array}{l}- \\
-\end{array}$ & $\begin{array}{c}0.864^{\circ} \\
\mathrm{n}=101\end{array}$ & $\begin{array}{l}0.578^{\circ} \\
\mathrm{n}=36\end{array}$ & $\begin{array}{l}0.839^{\circ} \\
\mathrm{n}=18\end{array}$ \\
\hline$B$ & & & $\begin{array}{l}- \\
-\end{array}$ & $\begin{array}{l}0.557^{\circ} \\
\mathrm{n}=36\end{array}$ & $\begin{array}{l}0.864^{\circ} \\
\mathrm{n}=18\end{array}$ \\
\hline C & & & & $\begin{array}{l}- \\
-\end{array}$ & $\mathrm{n}=0$ \\
\hline D & & & & & $\begin{array}{l}- \\
-\end{array}$ \\
\hline
\end{tabular}

to competent barnacle larvae. The hypothesis assumes well-mixed water within each site. This will increase the probability that a single settler would encounter the available suitable substrate. (Other processes related to the intensification hypothesis are dealt with in the 'Discussion'.) This hypothesis is an extension of the results of Bertness et al. (1992) who found that settlement intensified later in the settlement season, apparently as a result of favorable sites being filled by early-season settlers.

Inspection of Dike Rock settlement data showed that Site $O$ (the southernmost site, a rock $\sim 1.5 \mathrm{~m}$ diameter surrounded by sand) had consistently higher settlement than the other sites (Fig. 2); the decreased-substrate settlement-intensification hypothesis was suggested by this result. To test the hypothesis, settlement plates were installed in early July at Site D, the northernmost site (located, as Site O, on a rock surrounded by sand, but at the opposite extreme of the rocky shore). The hypothesis predicts that settlement should also be more intense at this site. Fig. 2 shows that Sites $O \& D$ appear to have higher settlement than Sites A \& B. (Sampling at Site C stopped when Site D started.) A Friedman non-parametric 2-way analysis of variance (sites = treatment effects; dates = blocks) showed evidence of significant differences among the 4 sites (Friedman test statistic $=23.33, \mathrm{df}=3 ; \mathrm{n}=18$, $\mathrm{p}<0.05$; rank sums for Sites O, A, B \& D were 65, 32, 34 and 49). Conover's (1980) multiple comparisons test showed that Site $O$ was different from Site $D(p<0.05)$, Site D was different from Site B $(p<0.05)$ and that Sites A \& B were not demonstrably different.

Table 2. Pollicipes polymerus. Spearman $r_{5}$ correlation coefficients among sites for settlement. $\cdot p \leq 0.05$

\begin{tabular}{|cccccc|}
\hline & $\mathrm{O}$ & $\mathrm{A}$ & $\mathrm{B}$ & $\mathrm{C}$ & $\mathrm{D}$ \\
\hline $\mathrm{O}$ & - & $0.782^{\circ}$ & $0.695^{\circ}$ & $0.509^{\circ}$ & $0.427^{\circ}$ \\
& - & $\mathrm{n}=55$ & $\mathrm{n}=55^{\circ}$ & $\mathrm{n}=36$ & $\mathrm{n}=18$ \\
$\mathrm{~A}$ & & - & $0.707^{\circ}$ & $0.425^{\circ}$ & $0.477^{\circ}$ \\
& & - & $\mathrm{n}=91$ & $\mathrm{n}=36$ & $\mathrm{n}=18$ \\
$\mathrm{~B}$ & & & - & $0.466^{\circ}$ & $0.702 \cdot$ \\
& & & - & $\mathrm{n}=36$ & $\mathrm{n}=18$ \\
$\mathrm{C}$ & & & & - & \\
& & & & - & $\mathrm{n}=0$ \\
$\mathrm{D}$ & & & & & \\
\end{tabular}




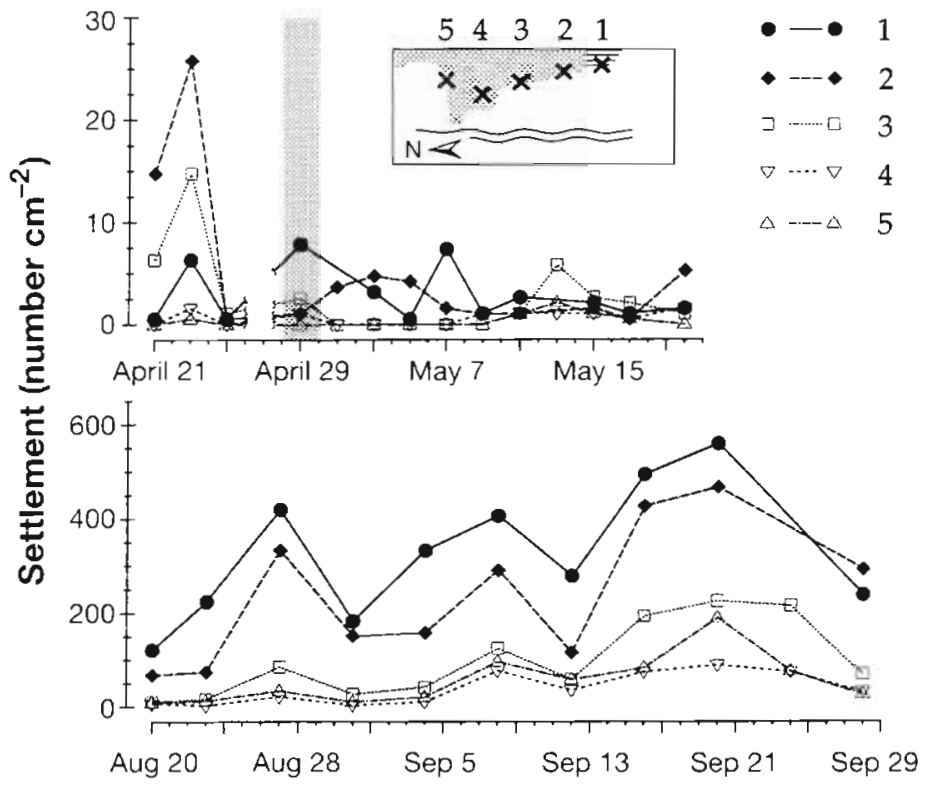

Fig. 4. Chthamalus spp. Settlement rate of metamorphosed spat plus attached cyprids at Medio Camino. Sampling at $4 \mathrm{~d}$ intervals in the lower panel and at $2 \mathrm{~d}$ intervals in the upper panel except $4 \mathrm{~d}$ for 29 April (shaded). Insert shows arrangement of sites, where dark shading represents the rocky area, the light shading the sandy shore and the hatched area (around Site 1) the rocky area inundated by sand in the August-September experiment

For Medio Camino, settlement intensities in AugustSeptember were conspicuously higher than in AprilMay (Fig. 4); the differences in sampling frequency could account for only about a factor of 2 in abundance. In addition to settlement intensities, other settlement patterns per site at Medio Camino in April-May contrast with those of August-September. Fig. 4 shows that the patterns of abundance per site per date are more consistently ordered by site in August-September than in April-May. In general, Site 1 appears to have consistently higher settlement than Site 2, and Site 2 higher than the other sites. In the April-May experiment, Sites $1 \& 2$ were about 30 to $40 \mathrm{~m}$ from a sandy beach, but in the August-September experiment, the sandy beach had extended laterally and Site 1 was then surrounded by sand (with no rocks between Site 1 and the sandy beach). By August, at Site 2, the sand level had reached the base of the rock where the plate was installed. The shore-extreme hypothesis predicts an intensification of settlement at Site 1 in August-September relative to other sites within the rocky shore. For April-May, there were no a priori expectations, and the results of this experiment can be used to test whether or not the ranking per site between the 2 sampling periods changed. Fig. 5 shows a histogram of the rank order per date for Site 1 in April-May and in August-September. The proportion of ranks 1 was much higher in AugustSeptember. There was evidence of statistically signifi- cant differences between the ranks-per-date for the 2 experiments (for Site 1, Mann-Whitney $U=95.000, \mathrm{p}<0.05)$.

\section{Proportion of unmetamorphosed settlers at Dike Rock}

Chthamalus spp, settlement was composed of unmetamorphosed settlers (attached cyprids) plus metamorphosed spat. The proportion of unmetamorphs tended to be small. Median proportions of unmetamorphosed settlers for Sites $O, A, B, C \& D$ was $0.030,0.048,0.035$, 0.044 and 0.022 . The time series of the proportion of unmetamorphs at Dike Rock was characterized by peaks, often covering several days and ranging up to $75 \%$, followed by lows (Fig. 6). The peaks lasted from 1 to $6 \mathrm{~d}$. There were no apparent monotonic increasing or decreasing trends in time or among stations. The proportion of unmetamorphosed settlers appears coherent among stations, particularly for Sites A \& B. Spearman correlation coefficients among sites (Table 3) were all significant. A Wilcoxon signed-rank test showed that the proportion of unmetamorphosed settlers was significantly different at Sites A and A-low $(z=-3.099 ; n=27$, with Site A being higher than Site A-low) while for Sites B \& B-low there was no evidence of consistent differences $(z=0.529, n=31)$.

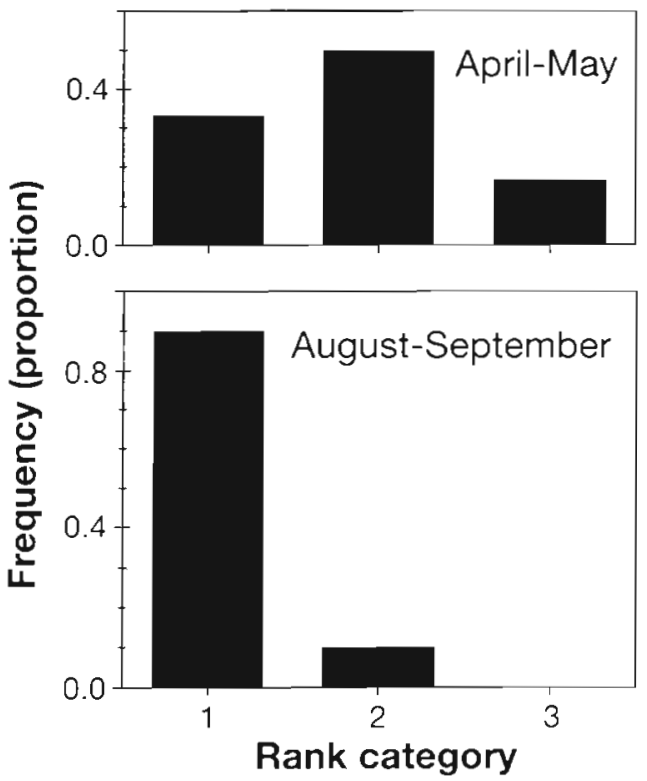

Fig. 5. Chthamalus spp. Frequency distribution of settlement ranks for Site 1 at Medio Camino in April-May and AugustSeptember experiments. For each date, settlement was ranked among the 5 sites (the site with greatest settlement had rank 1) 


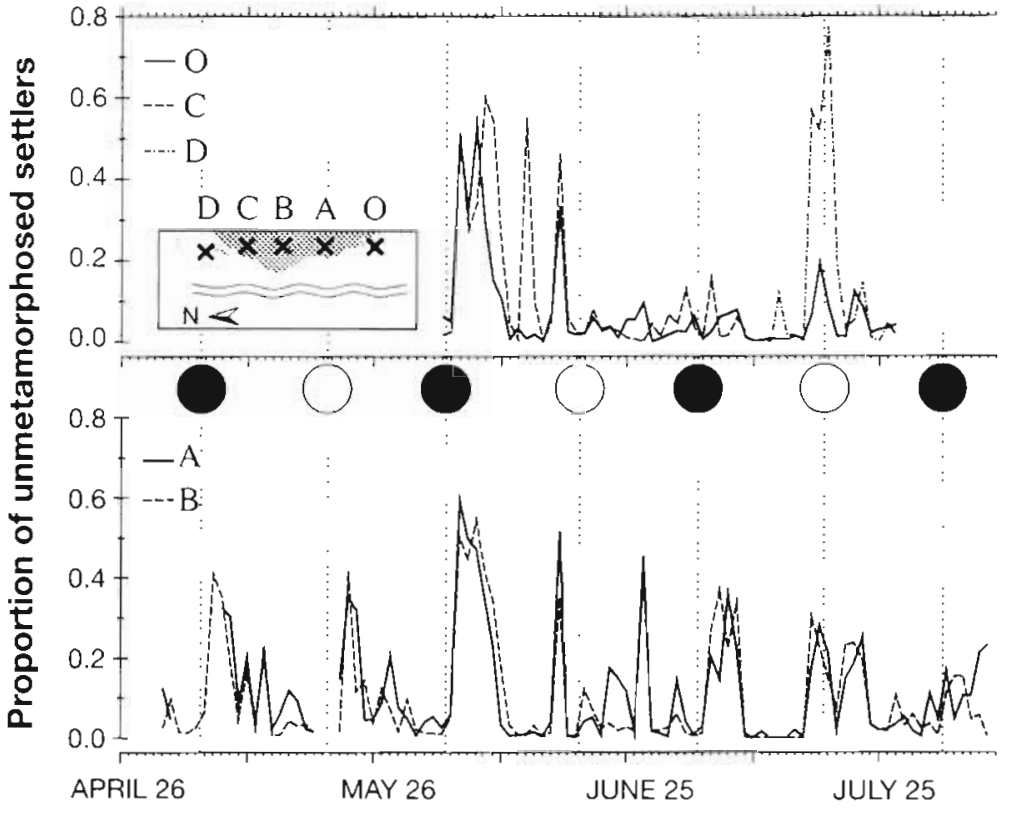

Fig. 6. Chthamalus spp. Proportion of unmetamorphosed settlers (attached cyprids/total settlement) at Dike Rock. Black and white circles represent new and full moon respectively. Other details as in Fig. 2
B, evaluated the periodicity of the proportion of unmetamorphs. Fig. 7 shows amplitude peaks close to the 14.75 period at both Sites A \& B. The theoretical breadth of the peaks (4.49 d), derived from period and sample size (Enright 1965), was similar to the empirical breadth of the peaks in Fig. 7

\section{Patterns in spat mortality at Dike Rock}

Spat mortality of Chthamalus spp. was variable in space and time (Fig. 8). Median mortalities for Sites O, A, B, C $\& D$ were $0.016,0.012,0.009,0.044$ and 0.013 . A Friedman non-parametric 2-way analysis of variance (sites = treatment effects; dates $=$ blocks) showed evidence of statistically significant differences among Sítes O, A, B \& C (rank sums for Sites $O, A, B$ \& $C$ were $90.5,91,63.5$ and 125 , Friedman test statistic $=30.87, \mathrm{df}=3$,
Fig. 6, tidal tables, and the personal observation that high proportions of unmetamorphosed settlers appeared correlated with larvae being left exposed to air by the descending tide suggested that the high proportions could be related to the short immersion time of the plates during the lower maxima in the semidiurnal inequalities prior sampling. (The semidiurnal inequality is the height difference between 2 semidiurnal minima or maxima in a mixed semidiurnal tide.) The semidiurnal inequality has fortnightly periodicity $(\sim 14.75 \mathrm{~d})$, and if the proportion of unmetamorphs is related to this phenomenon, then it might be expected that the proportion of unmetamorphs to total settlement might also have a fortnightly periodicity. A periodogram analysis of the 2 longest series, Sites A \&

Table 3. Chthamalus spp. Spearman $r_{\mathrm{s}}$ correlation coefficients among sites for proportion of unmetamorphs. $" p \leq 0.05$

\begin{tabular}{|cccccc|}
\hline & O & A & B & C & D \\
\hline O & - & $0.780^{\circ}$ & $0.750^{\circ}$ & $0.362^{\circ}$ & $0.593^{\circ}$ \\
& - & $\mathrm{n}=55$ & $\mathrm{n}=55^{\circ}$ & $\mathrm{n}=37$ & $\mathrm{n}=18$ \\
$\mathrm{~A}$ & & - & $0.768^{\circ}$ & $0.358^{\circ}$ & $0.625^{\circ}$ \\
& & - & $\mathrm{n}=91$ & $\mathrm{n}=37$ & $\mathrm{n}=18$ \\
$\mathrm{~B}$ & & & - & $0.402^{\circ}$ & $0.621^{\circ}$ \\
& & & - & $\mathrm{n}=37$ & $\mathrm{n}=18$ \\
$\mathrm{C}$ & & & & - & \\
$\mathrm{D}$ & & & & - & $\mathrm{n}=0$ \\
& & & & & - \\
\hline
\end{tabular}

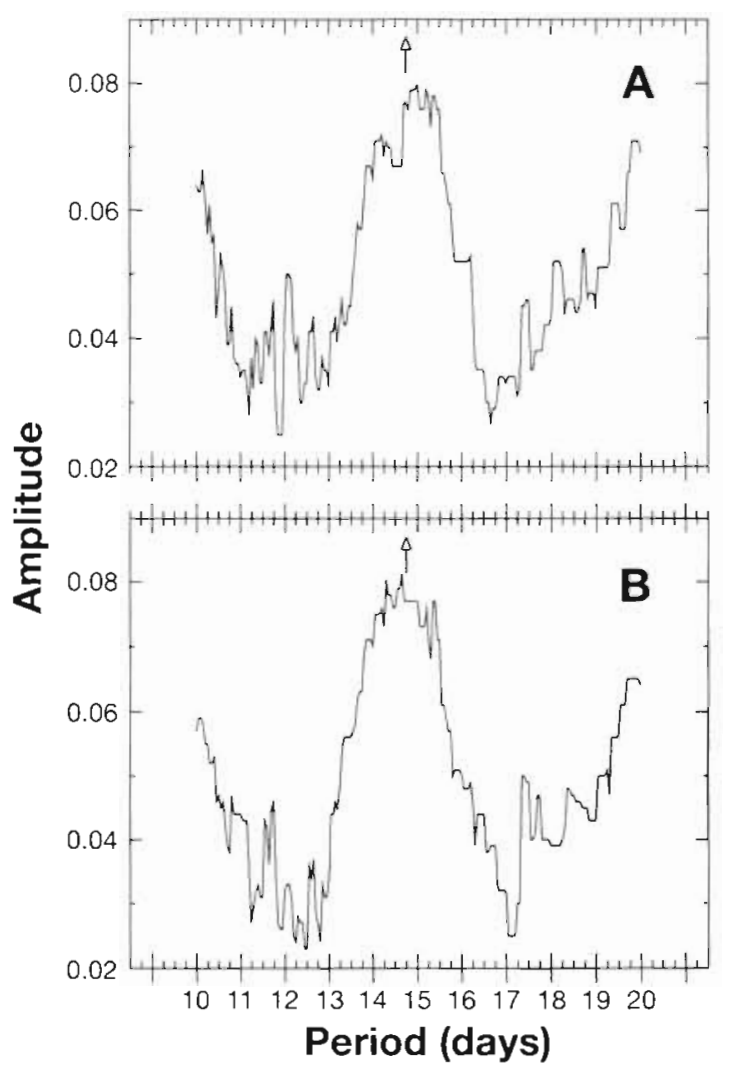

Fig. 7. Periodogram for the proportion of unmetamorphs to total settlement for time series at Sites A and B. See text for definition of amplitude. Period was calculated in $0.05 \mathrm{~d}$ intervals. Arrows point to fortnightly period (14.75 d) 


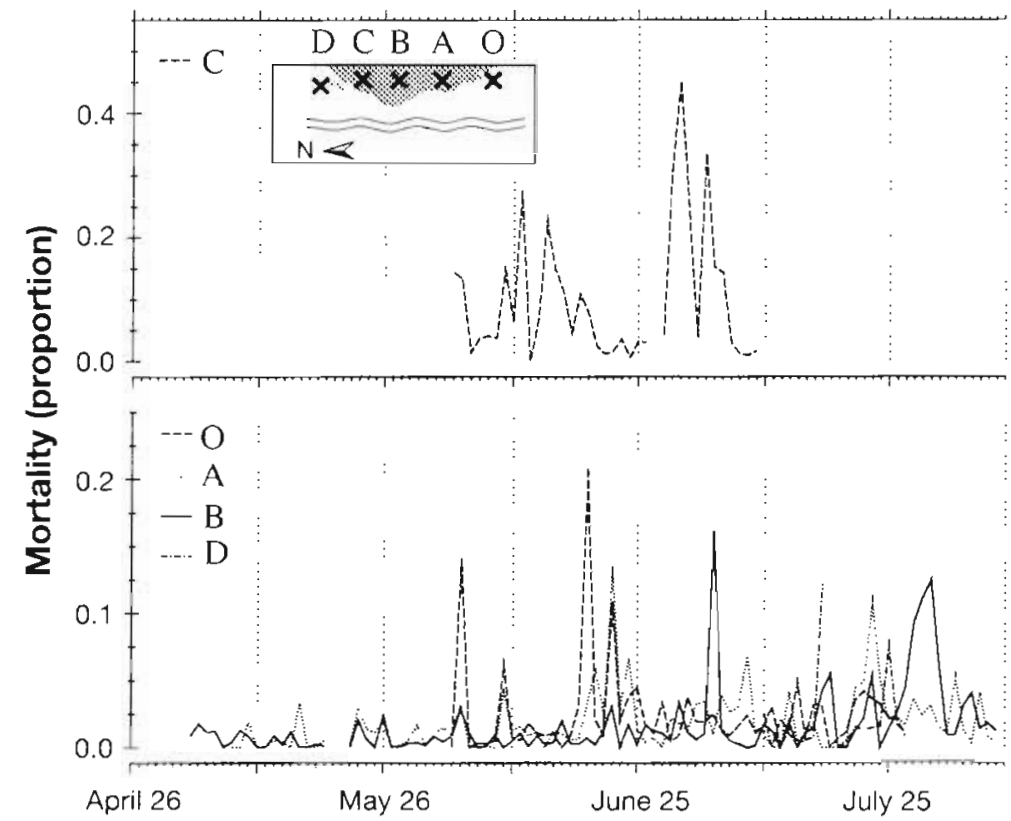

Fig. 8. Chthamalus spp. Mortality at Dike Rock. Details as in Fig 2

behavioral processes, and the availability of suitable substrate for settlement. It is argued that correlated settlement patterns in the 2 species (spatial and temporal settlement correlation) result from common events of onshore larval transport, while contrasting spatial patterns result from $P$. polymerus settlement being more influenced by behavior than that of Chthamalus spp. This is followed by discussion of the settlement intensification hypothesis, patterns in the proportion of unmetamorphosed cyprids, and patterns in mortality.

\section{Spatially correlated settlement}

Spatial settlement correlation among sites in Chthamalus spp. and Pollicipes polymerus, together with temporal correlations within sites between the 2 species, support the hypothesis that larvae of both

$\mathrm{n}=37, \mathrm{p}<0.05$ ). Conover's (1980) multiple comparisons test shows that both Site $\mathrm{C}$ and Site $\mathrm{B}$ were different from all sites $(p<0.05)$, and that Sites $O \& A$ were no different $(p>0.05)$; i.e. $\underline{C}$ OA $\underline{B}$. Table 4 shows Spearman correlation coefficients for Sites $\mathrm{O}$ to D. Correlation across dates was significant in the longest series (Sites A \& B) and only in 2 other cases.

\section{DISCUSSION}

In this section, settlement patterns in Chthamalus spp. and Pollicipes polymerus are compared and contrasted to explore the components of settlement influencing spatial and temporal variability along a shore: rate of larval input, micro-hydrodynamic and

Table 4. Chthamalus spp. Spearman $r_{s}$ correlation coefficients among sites for mortality. " $\mathrm{p} \leq 0.05$; ns: not significant

\begin{tabular}{|c|c|c|c|c|c|}
\hline & 0 & A & B & C & $\mathrm{D}$ \\
\hline $\mathrm{O}$ & - & $\begin{array}{l}0.505^{\circ} \\
\mathrm{n}=55\end{array}$ & $\begin{array}{l}0.125 \text { ns } \\
n=55\end{array}$ & $\begin{array}{c}-0.132 \mathrm{~ns} \\
\mathrm{n}=36\end{array}$ & $\begin{array}{l}0.082 \mathrm{~ns} \\
\mathrm{n}=17\end{array}$ \\
\hline A & & - & $\begin{array}{l}0.270^{\circ} \\
\mathrm{n}=91\end{array}$ & $\begin{array}{c}-0.097 \mathrm{~ns} \\
\mathrm{n}=36\end{array}$ & $\begin{array}{l}0.262 \mathrm{~ns} \\
n=17\end{array}$ \\
\hline B & & & $\begin{array}{l}- \\
-\end{array}$ & $\begin{array}{l}0.246 \mathrm{~ns} \\
\mathrm{n}=36\end{array}$ & $\begin{array}{l}0.418^{\circ} \\
\mathrm{n}=17\end{array}$ \\
\hline C & & & & $\begin{array}{l}- \\
-\end{array}$ & $\mathrm{n}=0$ \\
\hline $\mathrm{D}$ & & & & & - \\
\hline
\end{tabular}

species were being transported onshore by the same transporting events. It has previously been proposed that large internal tidal bores were primarily responsible for the onshore transport of Chthamalus spp. and $P$. polymerus larvae at Dike Rock in spring and summer; as predicted by the hypothesis, temperature was negatively correlated with settlement in the 2 species (Pineda 1991, but see also Shanks 1986, Shanks \& Wright 1987, Le Fèvre \& Bourget 1992). The spatial and temporal scales of the larval input could be similar to the scales of the physical transport mechanism. The duration of groups of large internal tidal bores, the proposed mechanism for the onshore larval transport of Chthamalus spp. and $P$. polymerus, is several days. Large internal tidal bores occur in groups of events of diurnal or semidiurnal periodicity which last from 1 to $9 \mathrm{~d}$ and are associated with a decrease in water temperature. Peaks in settlement during several consecutive days result from a group of large internal tidal bores. The spatial scale of large internal bores is not well known, but it appears to range from several hundred meters to a few kilometers (Pineda 1994). An alternative hypothesis to explain coherent settlement, that peaks in settlement would occur only when the water is covering the plates, would predict higher settlement at Sites A-low \& B-low. This hypothesis was not supported by the settlement results in Sites $A$-low \& B-low for Chthamalus spp. nor for Site A-low in $P$. polymerus. Settlement does not appear to be a direct function of intertidal height, nor of submersion times in this study. However, vertical differences in settlement must appear at some higher intertidal levels. Another 
hypothesis for sharp peaks in settlement is synchronous release of larvae by adults (Connell 1961), but Kendall et al. (1982) asserted that this idea does not explain the phenomenon, and Kendall et al. 1985 found that naupliar release appears to be a variable process that does not occur in peaks. In central Caljfornia, the hypothesis of synchronous release of larvae has been rejected for Balanus glandula and Chthamalus spp. on the basis of the lack of large pulses of larval release (Farrell et al. 1991). At Dike Rock, adult reproductive Chthamalus spp. appeared to occur year round, and competent larvae were found even in winter (pers. obs.). The synchronous release of larvae hypothesis does not explain the negative correlation between $P$. polymerus and Chthamalus spp. settlement with water temperature (Pineda 1991).

A noteworthy aspect of the settlement at Dike Rock is the abrupt decreases in settlement in both species from one day to the next; this suggest that the settlers disappear suddenly from the water around the plates as well as from the nearshore zone. The first step is obviously accomplished by falling tide. The second step could be explained by the nearshore vertical distribution of cyprids together with the dynamics of large internal bores. The center of distribution of cyprids in nearshore southern California was close to the bottom, in cold or thermocline waters, where the thermocline intersects the seafloor (Barnett \& Jahn 1987, Pineda 1991). When the thermocline tilts upward, the cyprids could be found close to the surface (pers. obs.). A large internal bore event will produce onshore advection of cold water through a shoaling of the thermocline. This upwelled water then recedes, 'sinking' seaward as a gravity current (the thermocline descends down), and it is replaced by warmer surface water (Pineda 1994). Peaks in settlement would result from the delivery of cyprids with the onshore advection of the cold water. Abrupt decreases would result from the subsequent sinking of the same cold water.

\section{Contrasting patterns in the 2 species}

Other spatial and temporal patterns in Chthamalus spp. and Pollicipes polymerus settlement were strikingly different. The bulk of all $P$. polymerus settlement at Sites A \& B occurred in a single 3 to $8 \mathrm{~d}$ peak; for single-day comparisons, this settlement was larger than others by a factor of 9 at Site A and 30 at Site B. For Chthamalus spp., there were 5 big peaks with relatively little difference among them. Hoffman (1989) counted $P$. polymerus $<1 \mathrm{~mm}$ in rostro-carinnal length (estimated to be 1 to $3 \mathrm{~d}$ old) on adult peduncles, and found settlement year round with peaks in March and April. Shanks (1986) studied daily Chthamalus spp. settlement at Dike Rock from April to late June and found 6 peaks, while from August to early November 4 peaks were found. Different peaks in $P$. polymerus and Chthamalus spp. could have been caused by differences in the larval pool, in physical transport processes, or both. Differences in physical transport processes for the 2 species is unlikely because Chthamalus spp. did not show such dissimilar peaks, and because both species seem to be transported by the same physical transport phenomenon (Pineda 1991). In consequence, the most parsimonius explanation to explain dissimilar peaks in Chthamalus spp. and $P$. polymerus is that differences were related to the availability of larvae to be transported by larval pool phenomena.

Chthamalus spp. settlement at the 5 sites was about the same order of magnitude, but Pollicipes polymerus settlement was by far highest at Site B. For vertical comparisons, there were no vertical differences in settlement for Chthamalus spp., but $P$. polymerus settlement at Site B was higher than Site B-low, and Site A was lower than Site A-low. The most parsimonious explanation for similar Chthamalus spp. settlement at Sites A, A-low, B \& B low is that number of settling larvae available were similar at these sites. Dissimilar settlement of $P$. polymerus could be explained by consistent differences in rate of larvae arriving at each of the sites, by concentration or diffusion of larvae by site specific micro-hydrodynamic processes, or by strong behavioral preferences at settlement. The explanation that dissimilar settlement at Sites A \& B were due to differences in P. polymerus larval input or micro-hydrodynamics requires invoking a process that would concentrate $P$. polymerus larvae in Sites A-low \& B (as compared to Sites A \& B-low), and, in addition, this process could not operate on Chthamalus spp. larvae. The alternative, more parsimonious explanation, is that $P$. polymerus settlement was intensified by behavior at Sites A-low and Site B (relative to Sites A \& B-low), whereas Chthamalus spp. was a less discriminating settler.

The hypothesis that settlement is intensified by behavior in Pollicipes polymerus but far less in Chthamalus spp. was not critically tested. A comparative analysis of the ecology of the 2 species, however, could help to evaluate the hypothesis. The adult distribution patterns could be determined during settlement or at the juvenile-adult stage. Strong behavioral differences during settlement might well lead to restricted adult distributions, while indiscriminate settlement might produce a more widespread distribution. Barnes \& Reese (1960) documented strongly constrained distributions for $P$. polymerus (which tends to be found in wave-swept sites), while Chthamalus fissus (the most abundant Chthamalus species in southern California; 
Morris et al. 1980) is much less restricted than $P$. polymerus, occurring in both exposed and protected habitats (Rickets \& Calvin 1968, Morris et, al. 1980, pers. obs.) Within sites, $P$. polymerus adult distribution depends on micro-topographic features; adults align their feeding cirri to fast currents (resulting from breaking waves channeled by topography) rather than to breaking waves (Barnes \& Reese 1960). P. polymerus also requires strong currents to initiate its feeding, and Crisp \& Southward (1961) reported that the P. polymerus type of feeding ('cirral extension') together with their strong, insensitive cirri, is well adapted for dealing with energetic, fast current environments. However, Lewis (1981) reported juvenile $P$. polymerus utilizing 'normal beat' (another type of feeding in barnacles). P. polymerus tend to align to unidirectional currents by turning their capitulum relatively slowly (Barnes \& Reese 1960) with little capability of cirral rotation; in contrast, balanomorph barnacles such as Chthamalus spp. have much better capabilities for rotating their cirri (see Anderson \& Southward 1987 for a review); presumably, rotation of cirri would be a fasiel and more uscful response in variable current environments. In sum, behaviorally intensified settlement by $P$. polymerus would correspond to more restricted distribution of this species, while less discriminate behavior at settlement by Chthamalus spp. would fit its known characteristics. It is not known what mechanisms are involved in the settlement intensification of $P$. polymerus; although $P$. polymerus settles preferentially on adult peduncles (Barnes \& Reese 1960, Lewis 1975, Hoffman 1989), settlement plates were at least $50 \mathrm{~cm}$ away from established $P$. polymerus adults. Settlement on primary substrate, of course, is also common (Hoffman 1989, W. Newman pers. comm., this study). Another possibility is that $P$. polymerus larvae prefer to settle in sites with strong unidirectional flows; a subjective evaluation of Sites B \& A low suggested that in both sites unidirectional fast currents result from channeling, directing and speeding breaking waves by local topography. (Site A-low was on a large, $\sim 3 \mathrm{~m}$ diameter, somewhat flat rock, while Site B was on a $\sim 15$ m raised rocky ledge at $\sim 10$ to $30^{\circ}$ angle with the nearshore shallow isobath contours.)

\section{Decreased-substrate settlement-intensification hypothesis}

Previous explanations of temporal and spatial variability in settlement have invoked variability in larval input and micro-hydrodynamic and behavioral processes (see Connell 1985 for a review), as well as changes in larval concentration as the water is 'drained' of larvae. Gaines et al. (1985) found that sites separated at ca 30 to $60 \mathrm{~m}$ in a cross-shore direction had different settlement rates (measured as weekly rates); they proposed that seaward sites would 'drain' out larvae from onshore moving water, so that seaward sites would have higher settlement rates. In a similar manner, a longshore surf current could result in more settlement at one extreme of the rocky shore, and progressively less settlement as the water moves on. This hypothesis does not appear to explain the results discussed here because at Dike Rock there was not an ordered decrease in settlement, from one extreme of the rocky shore to the other. The 2 sites with most settlement were both at the extremes of the rocky shore. For Medio Camino, the hypothesis would not explain the change in settlement ranks unless one makes the arbitrary assumption of a change in surf currents between the 2 dates.

The hypothesis offered here coincides with that of Bertness et al. (1992) in explaining that available settlement area is important in understanding spatial variation between sites and temporal variation within sites. The hypothesis predicts that settlement intensification should occur at shore extremes or where available settlement area could become limiting. Temporal variability in substrate available for settlement can also be predicted in some cases; the monopolization and release of space in the intertidal by competitively dominant species as well as biological and physical disturbances is common in many studied systems (e.g. Hatton 1938, Connell 1961, Dayton 1971, Paine \& Levin 1981, Taylor \& Littler 1982, but see Underwood \& Fairweather 1986). Favorable settlement sites could be occupied early in the season (e.g. Bertness et al. 1992). Seasonal sand-inundation is predictable in many shores of California (Taylor \& Littler 1982, Stewart 1983) and Pacific Baja California (pers. obs.). Seasonal inundation would produce intensification in settlement at the sites most influenced by the sand. At shores where sites are differentially influenced, as was the case for Medio Camino, settlement intensification would produce a more ordered pattern in the abundance of settlers per site.

Gaines \& Roughgarden (1985) found that the relative numbers of cyprids settling in a portion of a quadrat was directly proportional to the free area available for settlement (see also Minchinton \& Scheibling 1993), and proposed that number of larvae is directly proportional to free area available for settlement. The hypothesis offered here is that when free settlement area is scarce, settlement rate increases over the remaining available substrate. There is no contradiction because the results of Gaines \& Roughgarden (1985) refer to total settlement within a specified, small-scale system, while the hypothesis presented here is intended to explain differences in settlement rate over free sub- 
strate between sites separated $>10 \mathrm{~m}$, and in a system where the total free space changed. Within a site ('system'), and as long as free space and 'surrounding conditions' are kept fairly constant, total settlement rate might be proportional to available area; among sites, or when free settlement area decreases, settlement rate would be inversely related to free area available for settlement.

Effects of settlement intensification would be more marked for species such as Chthamalus spp., which showed less selectivity. For species such as Pollicipes polymerus, effects might be difficult to detect because behavioral interactions would override intensification. The intensification hypothesis is probably best tested for sites along a shore where larval input tends to be similar, and this might require estimates of watercolumn larval abundance (For example, while Sites $O$ \& D had higher rates than other sites, Site $O$ had higher settlement than Site D, and in consequence, other processes might be involved in settlement differences.) Other processes that produce settlement variability at the shore scale might confound or be confounded with intensification by decreased area effects. For example, in this study, some plates within sites tended to have consistently higher settlement rate than others, and these sites appeared to be characterized by longer residence times of seawater than the other sites (Pineda unpubl.).

\section{Unmetamorphosed settlers}

Few studies have documented patterns in the proportion of metamorphosed vs unmetamorphosed spat in the field; Pyefinch (1948) asserted that metamorphosis took up to $48 \mathrm{~h}$ in field populations of Semibalanus balanoides, and Connell (1961) found an average of $1.5 \mathrm{~d}$ between attachment and metamorphosis in the same species. Barry (1988) found that settlement of attached larvae over soft and hard rock at Dike Rock was nearly equal, but that metamorphosed spat counts were higher over the harder rock, suggesting that while results could reflect difference in metamorphosis success at the 2 substrates, it might also indicate differences in early survival of the settlers.

The small proportion of Chthamalus spp. unmetamorphosed cyprids to total settlement indicates that most larvae metamorphosed to spat in less than $1 \mathrm{~d}$. The occurrence of high proportions of unmetamorphs appeared correlated to larvae being left exposed to air by the declining sea level (pers. obs.). The $\sim 14.75 \mathrm{~d}$ periodicity in the proportion of unmetamorphs support this hypothesis, suggesting that peaks may be related to restricted immersion times of the plates due to periodic variability in the semidiurnal inequality. The result at Site $A$, that the proportion of unmetamorphs was higher at Site A than at Site A-low, supports this hypothesis, but the absence of such a consistent difference between between Sites B \& B-low could be taken as evidence against the proposal.

The population effects of high proportions of unmetamorphosed settlers is not known. Connell (1961) found that mortality of attached cyprids was higher during warm, calm days and in periods of strong winds (gales), and concluded that metamorphosed barnacles suffered less mortality than cyprids in hot weather. Furthermore, recruit mortality was higher in strong winds and he suggested that it was probably due to barnacles being hit by particles moved by waves. In this study, cyprids attached to plates could be readily induced to metamorphose when submerged in water (pers. obs.). Attached cyprids do not feed and might be easier to dislodge by water turbulence or removed by crabs (see below) than metamorphosed spat.

\section{Patterns in Chthamalus spp. spat mortality}

Other studies (e.g. Denley \& Underwood 1979) have reported that mortality of young recruits was correlated with desiccation. In this study, mortality was highest at Site $C$ and tended to increase during the study period. Only mortality related to direct physical damage was measured, and it was positively correlated among sites in the 2 longest records. This suggests that mortality might be related to a physical phenomenon with scales larger than $50 \mathrm{~m}$ (such as wave action.) Physical abrasion or crushing can result from waterborne objects, as suggested by Connell (1961). It appeared that Site $C$ had the highest wave energy, and waves loaded with some sand breaking over recently metamorphosed spat might cause mortality. On a few occasions, a grain of sand or a piece of mica was found encrusted on the spat. Correlated mortality in the longest series suggests a mortality agent operating at these scales. Increased mortality might be related to increased sand loading due to seasonal sand inundation and/or change in wave patterns.

An unquantified factor of mortality was predation by the lined crab Pachygrapsus crassipes and an unidentified nemertean (Emplectonema gracile?). Strong evidence of $P$. crassipes predation on attached cyprids was the finding of $P$. crassipes fecal pellets full of cyprid shells after heavy settlements, while on occasion a nemertean was found on settlement plates showing evidence of predation (e.g. a 'row' of spat missing in the same plate groove where the nemertean was found). Finally, it was observed that heavy settlement of Pollicipes polymerus tended to dislodge metamorphosed spat and attached Chthamalus spp. cyprids. 


\section{CONCLUSIONS}

The main conclusion of this paper is that while temporal variability appeared to be related to the larval pool and to physical transport processes, spatial variability along the shore at the $100 \mathrm{~m}$ scale was related to behavioral phenomena and substrate variability. Micro-hydrodynamic phenomena, which by definition have small scales, might also produce spatial variability. At larger spatial scales, however, larval-pool size and physical transport might predominate, because they are characterized by coarse and meso-scale variability. Fig. 1 reflects the a priori arguments that can be made about the relative importance of the proximate components of settlement. As suggested by Fig. 1, the rate of the arrival of the larvae determines the number of larvae available to hydrodynamic processes, substrate availability and behavioral processes. For example, with no larvae in the larval pool or with no larvae being transported onshore, behavioral, microhydrodynamic, and substrate availability processes would not be operative. Thus, one might well propose that variablity in the larval pool and physical transport processes are the dominant processes in influencing settlement rate.

A recent research program (summarized in Connell 1985) has focused on distinguishing settlement vs recruitment processes in determining population abundance. Several studies have found that settlement was important in determining population abundance (Denley \& Underwood 1979, Raimondi 1990, Minchinton \& Scheibling 1991, Gaines \& Bertness 1992, Bertness et al. 1992; see also Connell 1985 for a review). A study like this, on settlement rate alone, cannot assess the importance of settlement in determining population abundance. A justification for studying settlement rate alone, however, is that settlement rate is a phenomenologically complex phenomenon. A single study, even on settlement rate alone, can hardly address all the aspects involved. Full understanding of settlement rate implies knowledge of the larval pool, physical transport processes, micro-hydrodynamics, substrate availability and behavioral processes (Fig. 1). This knowledge appears essential to understand and predict local and geographical variability in population abundance and distribution.

Acknowledgements. Dave Checkley, Paul Dayton, Jim Enright, Loren Haury, Bill Newman and Eric Vetter critically read the manuscript. I appreciate the thorough review of 3 anonymous referees. Settlement data at Medio Camino (and at many other Baja California sites) was obtained with aid from the Tinker Foundation. I also acknowledge a Mathias Award from the Natural Reserve System of the University of California. Jim Enright provided the computer program for cal- culating the periodogram and discussed dozens of results obtained with it. The help of Erika Del Castillo with all aspects of this study was critical. The people of Mexico supported this research through a CONACYT graduate fellowship.

\section{LITERATURE CITED}

Anderson, D. T., Southward, A. J. (1987). Cirral activity of barnacles. In: Southward, A. J. (ed.) Barnacle biology. A.A. Balkema, Rotterdam, p. 135-174

Barnes, H. Reese, E. S. (1960). The behaviour of the stalked intertidal barnacle Pollicipes polymerus J. B. Sowerby. with special reference to its ecology and distribution. J. Anim. Ecol. 29: 169-185

Barnett, A. M., Jahn, A. E. (1987). Pattern and persistence of a nearshore planktonic ecosystem off Southern California. Cont. Shelf Res. 7: 1-25

Barry, J. P. (1988) Pattern and process: patch dynamics in a rocky intertidal community in Southern California. Ph.D. thesis, University of California, San Diego

Bennell, S. J. (1981). Some observations on the littoral barnacle populations of north Wales. Mar. environ. Res. 5: $227-240$

Bertness, M. D., Gaines, S. D., Stephens, E. G., Yund, P. O. (1992). Components of recruitment in populations of the acorn barnacle Semibalanus balanoides (Linnaeus). J. exp. mar. Biol. Ecol 156: 199-215

Bousfield, E. L. (1955). Ecological control of the occurrence of barnacles in the Miramichi estuary. Nat. Mus. Can. Bull. 137: $1-69$

Bushek, D. (1988). Settlement as a major determinant of intertidal oyster and barnacle distributions along a horizontal gradient. J. exp. mar. Biol. Ecol. 122: 1-18

Butman, C. A. (1987). Larval settlement of soft-sediment invertebrates: the spatial scales of pattern explained by active habitat selection and the emerging rôle of hydrodynamical processes. Oceanogr. mar. Biol. A. Rev. 25: 113-165

Caffey, H. M. (1985). Spatial and tempora] variation in settlement and recruitment on intertidal barnacles. Ecol. Monogr. 55: 313-332

Connell, J. H. (1961). Effects of competition, predation by Thais lapillus, and other factors on natural populations of the barnacle Balanus balanoides. Ecol. Monogr. 31: $61-104$

Connell, J. H. (1985). The consequences of variation in initial settlement vs post-settlement mortality in rocky intertidal communities. J. exp. mar. Biol. Ecol. 93: 11-45

Conover, W. J. (1980). Practical nonparametric statistics, 2nd edn. Wiley, New York

Crisp, D. J. (1976). Settlement responses in marine organisms. In: Newell, R. C. (ed.) Adaptation to environment: essays on the phyisology of marine animals. Butterworths, London, p. 83-124

Crisp, D. J., Barnes, H. (1954). The orientation and distribution of barnacles at settlement with particular reference to surface contour. J. Anim. Ecol. 23: 142-162

Crisp, D. J., Southward, A. J. (1961). Different types of cirral activity of barnacles. Phil. Trans R. Soc. Lond. B 243: $271-307$

Dayton, P. K. (1971). Competition, disturbance, and community organization: the provision and subsequent utilization of space in a rocky intertidal community. Ecol. Monogr. 41: 351-389 
Dayton, P. K., Carleton, J. H., Mackley, A. G., Sammarco, P. W. (1989). Patterns of settlement, survival and growth of oysters across the Great Barrier Reef. Mar. Ecol. Prog. Ser. 54: 75-90

De Wolf, P. (1973). Ecological observations on the mechanisms of dispersal of barnacle larvae during planktonic life and settling. Neth. J. Sea Res. 6: 1-129

Denley, E. J., Underwood, A. J. (1979). Experiments on factors influencing settlement, survival, and growth of two species of barnacles in New South Wales. J. exp. mar. Biol. Ecol. 36: 269-293

Eckman, J. E. (1983). Hydrodynamic processes affecting benthic recruitment. Limnol. Oceanogr. 28: 241-257

Enright, J. T. (1965). The search for rhythmicity in biological time-series. J. theor. Biol 8: 426-468

Farrell, T. M., Bracher, D., Roughgarden, J. (1991). Crossshelf transport causes recruitment to intertidal populations in central California. Limnol. Oceanogr. 36: 279-288

Gaines, S., Brown, S., Roughgarden, J. (1985). Spatial variation in larval concentrations as a cause of spatial variation in settlement for the barnacle, Balanus glandula. Oecologia 67: 267-272

Gaines, S., Roughgarden, J. (1985). Larval settlement rate: a leading determinant of structure in an ecological community of the marine intertidal zone. Proc. natl Acad. Sci. U.S.A. 82: 3707-3711

Gaines, S. D., Bertness, M. D. (1992). Dispersal of juveniles and variable recruitment in sessile marine species. Nature 360: $579-580$

Grosberg, R. K. (1982). Intertidal zonation of barnacles: the influence of planktonic zonation of larvae on vertical distribution of adults. Ecology 63: 894-899

Hatton, H. (1938). Essais de bionomie explicative sur quelques espèces intercotidales d'algues et d'animaux. Annls Inst. océanogr. Monaco 17: 241-238

Hawkins, S. J., Hartnoll, R. G. (1982). Settlement patterns of Semibalanus balanoides (L.) in the lsle of Man (1977-1981). J. exp. mar. Biol. Ecol. 62: 271-283

Hoffman, D. L. (1989). Settlement and recruitment patterns of a pedunculate barnacle, Pollicipes polymerus Sowerby, off La Jolla, California. J. exp. mar. Biol. Ecol. 125: 83-98

Johnson, M. W. (1939). The correlation of water movements and dispersal of pelagic larval stages of certain littoral animals, especially the sand crab, Emerita. J mar. Res. 2: $236-245$

Johnson, M. W. (1960). The offshore drift of larvae of the California spiny lobster Panulirus interruptus. Calif. coop. ocean. Fish. Invest. Rep. 7: 147-161

Johnson, L. E., Strathmann, R. R. (1989). Settling barnacle larvae avoid substrata previously occupied by a mobile predator. J. exp. mar. Biol. Ecol. 128: 87-103

Kendall, M. A., Bowman, R. S., Williamson, P., Lewis, J. R. (1982). Settlement patterns, density and stability in the barnacle Balanus balanoides. Neth. J. Sea Res. 16: $119-126$

Kendal, M. A., Bowman, R. S., Williamson, P., Lewis, J. R. (1985). Annual variation in the recruitment of Semibalanus balanoides on the north Yorkshire coast 1969-1981. J. mar. biol. Ass. U.K. 65: 1009-1030

Keough, M. J., Downes, B. J. (1982). Recruitment of marine invertebrates: the role of active larval choices and early mortality. Oecologia 54: 348-352

Knight-Jones, E. W. (1953). Laboratory experiments on gregariousness during settling in Balanus balanoides and other barnacles. J. exp. Biol. 30: 584-598 plus 1 plate

Korringa, P. (1941). Experiments and observations on swarming, pelagic life and setting in the European flat oyster,
Ostrea edulis L. Arch. néerl. Zool. 5: 1-249

Le Fèvre, J., Bourget, E. (1992). Hydrodynamics and behaviour: transport processes in marine invertebrate larvae. Trends Ecol. Evol. 7: 288-289

Lewis, C. A. (1975). Development of the gooseneck barnacle Pollicipes polymerus (Cirripedia: Lepadomorpha): fertilization through settlement. Mar. Biol. 32: 141-153

Lewis, C. A. (1981). Juvenile to adult shift in feeding strategies in the pedunculate barnacle Pollicipes polymerus Sowerby (Cirripedia: Lepadomorpha). Crustaceana 41 : $14-20$

Minchinton, T. E., Scheibling, R. S. (1991). The influence of larval supply and settlement on the population structure of barnacles. Ecology 72: 1867-1879

Minchinton, T E., Scheibling, R. S. (1993). Free space availability and larval substratum selection as determinants of barnacle population structure in a developing rocky intertidal community. Mar. Ecol. Prog. Ser. 95: 233-244

Morris, R. H., Abbott, D. A., Harderlie, E. C. (1980). Intertidal invertebrates of California. Stanford University Press, Stanford

Paine, R. T. (1966). Food web complexity and species diversity. Am. Nat. 100:65-75

Paine, R. T., Levin, S. A. (1981). Intertidal landscapes: disturbance and the dynamics of pattern. Ecol. Monogr. 51: $145-178$

Pineda, J (1991). Predictable upwelling and the shoreward transport of planktonic larvae by internal tidal bores. Science 253: 548-551

Pineda, J. (1994). Internal tidal bores in the nearshore: warmwater fronts, seaward gravity currents and the onshore transport of neustonic larvae. J. mar. Res. 52(3): in press

Pyefinch, K. A. (1948). Notes on the biology of cirripedes. J. mar biol. Ass. U.K. 27:464-503

Raimondi, P. I. (1990). Patterns, mechanisms, consequences of variability in settlement and recruitment of an intertidal barnacle. Ecol. Monogr. 60: 283-309

Raimondi, P. T (1991). Settlement behavior of Chthamalus anisopoma larvae largely determines the adult distribution. Oecologia 85: 349-360

Raimondi, P. T., Keough, M. J. (1990). Behavioural variability in marine larvae. Aust. J. Ecol 15:427-437

Ricketts, E. F., Calvin, J. (1968). Between Pacific tides (revised by J. W. Hedgpeth, 4th edn). Stanford University Press, Stanford

Roughgarden, J., Gaines, S., Possingham, H. (1988). Recruitment dynamics in complex life cycles. Science 241: $1460-1466$

Scheltema, R. S. (1986). On dispersal and planktonic larvae of benthic invertebrates: an eclectic overview and summary of problems. Bull. mar. Sci. 39: 290-322

Schuster, A. (1898). On the investigation of hidden periodicities with application to a supposed 26-day period of meteorological phenomena. Terr. Magn. Atmos. Electr. 3: $13-41$

Shanks, A. L. (1983). Surface slicks associated with tidally forced internal waves may transport pelagic larvae of benthic invertebrates and fishes shoreward. Mar Ecol. Prog. Ser. 13: 311-315

Shanks, A. L. (1986). Tidal periodicity in the daily settlement of intertidal barnacle larvae and an hypothesized mechanism for the cross-shelf transport of cyprids. Biol. Bull. 170: $429-440$

Shanks, A. L., Wright, W. G. (1987). Internal-wave mediated shoreward transport of cyprids, megalopae, and gammanids and correlated longshore differences in the settling rate of intertidal barnacles. J. exp. mar. Biol. Ecol. 114: 1-13 
Stewart, J. G. (1983). Fluctuations in the quantity of sediments trapped among thalli on intertidal rock platforms in southern California. J. exp. mar. Biol. Ecol. 73: 205-211

Strathmann, R. R., Branscomb, E. S., Vedder, K. (1981). Fatal errors in set as a cost of dispersal and the influence of intertidal flora on set of barnacles. Oecologia 48: 13-18

Taylor, P. R., Littler, M. M. (1982). The roles of compensatory mortality, physical disturbance, and substrate retention in the development and organization of a sand-influenced, rocky-intertidal community. Ecology 63: 135-146

Thorson, G. (1950). Reproductive and larval ecology of marine bottom invertebrates. Biol. Rev. Camb. Phil. Soc. 25: 1-45

Underwood, A. J., Fairweather, P. G. (1986). Intertidal communities: do they have different ecologies or different

This article was presented by $N$. Holland, La Jolla, California, USA ecologists? Proc. ecol. Soc. Aust. 14:7-16

Wethey, D. S. (1984). Spatial pattern in barnacle settlement: day to day changes during the settlement season. J. mar. biol. Ass. U.K. 64: 687-698

Wethey, D. S. (1986). Local and regional variation in the settlement and survival in the littoral barnacle Semibalanus balanoides (L.): patterns and consequences. In: Moore, P. G., Seed, R. (eds.) The ecology of rocky coasts. Columbia University Press, New York, p. 194-202

Young, C. M. (1988). Larval predation by barnacles: effects of patch colonization in a shallow subtidal community. Ecology 69: 624-634

Young, C. M. (1990). Larval ecology of marine invertebrates: a sesquicentennial history. Ophelia 32: 1-48

Manuscript first received: September 17, 1993

Revised version accepted: January 18, 1994 